\title{
FAILURE OF FIBERCONCRETE BEAM HAVING LAYERED STRUCTURE
}

\author{
Vitalijs Lusis ${ }^{1}$, Andrejs Krasnikovs ${ }^{2}$ \\ ${ }^{1}$ Institute of Building Production, Faculty of Civil Engineering, RTU Concrete Mechanics Laboratory, Riga Technical \\ University, Azenes Str. 16/20, LV-1048, Riga, Latvia \\ ${ }^{2}$ Institute of Mechanics, RTU Concrete Mechanics Laboratory, Riga Technical University, Ezermalas Str. 6, LV-1006, \\ Riga, Latvia \\ E-mail:IVitalijs.Lusis@rtu.lv(correspondingauthor); 2akrasn@latnet.lv
}

\begin{abstract}
As it has been found out, fiberconcrete has many positive attributes, which make that material a target of the numerous investigations. Traditionally fibers are homogeneously dispersed in the concrete volume. At the same time, in many situations fiber reinforced concrete with homogeneously dispersed fibers is not optimal (the majority of added fibers do not participate in the load bearing process). In the present investigation it has been demonstrated that the use of homogeneous fiberconcrete in eccentrically loaded and subjected to bending structures is not rational from mechanical and economical point of view. Fiber reinforced concrete prisms with homogeneous and layered fiber distribution inside them were elaborated. Prisms were tested under four point bending till macro-crack opening of $4 \mathrm{~mm}$ and more was reached. Load bearing capacities at different load bearing stages of differently made prisms were compared.
\end{abstract}

Keywords: non-homogeneous fiberconcrete, layered distribution, steel fibers, failure.

\section{Introduction}

The aim of the present research is to create and investigate a fiberconcrete construction with nonhomogeneous fiber distribution in it. Layered beams with layers having different fiber content in plies were fabricated (in this research prisms with dimensions $100 \times 100 \times 400 \mathrm{~mm}$ were created) (Lusis \& Krasnikovs 2013a). It is obvious that the formation of construction having non-homogeneous distribution of fibers in it is possible in different ways. For example, some technologies of specimen preparation are described in Latvian invention patent No. 14257 "Technology process and device for manufacturing fiberconcrete nonhomogeneous structural elements" (Lapsa et al. 2011), Latvian invention patent No. 14667 "Method for oriented reinforcement of fiberconcrete structures prior to concreting" (Lusis \& Krasnikovs 2013b) and Latvian invention patent No. 14684 "Method for orienting fibers in fiber reinforced concrete" (Lusis \& Krasnikovs 2013c). Beams were fabricated, matured (28 days) and tested under four point bending conditions.

Important problem for fiberconcrete is fiber orientation in the sample. Some sources maintain that the structure created by the oriented fibers, which are placed upon the stress distribution with uniform concentration throughout the sample volume, is not recommended for the site conditions because there is limited supply of necessary equipment and quality control (Roik, K. \& Dieckmann, C., Schwalbenhofer 1987; Nicolay 1984; Schorn 1985). In the present investigation oriented fiber introduction method described in (Lusis \& Krasnikovs 2013a) was experimentally validated.

Tensile forces are concentrated in bended prism part below the neutral axis. Geometrical location of the neutral axis was determined during loading.

\section{Materials and methods}

The aim of the present research is to create fiberconcrete construction with non-homogeneous fiber distribution in it.

Two types of fibers were used in the experiments:

a) $30 \mathrm{~mm}$ long and $0.38 \mathrm{~mm}$ in diameter steel-hooked fibers Dramix RC-80/30-BP (with aspect ratio $1 / \mathrm{d}=79)$;

b) $60 \mathrm{~mm}$ long and $0.71 \mathrm{~mm}$ in diameter steel-hooked fibers Dramix RC-80/60-BP (with aspect ratio $1 / \mathrm{d}=85$ ) (Bekaert 2013).

Fibers are commercially available and are produced by N.V. Bekaert S.A., Belgium.

Some technology steps in non-homogeneous fiberconcrete structure fabrication process of concrete containing mineral components, water and additives mixture preparation without fibers, placing and compaction of the material in the mould, followed by uniformly scattering the fibers on the concrete surface in the mould and pressing fibers into the concrete (this operation was carried out by a lattice) are described in Latvian invention patent No. 14257 "Technology process and device for manufacturing fiberconcrete non-homogeneous structural elements".

Layered beams with different short fiber content in plies were fabricated. Second technology of specimen fabrication can be found in Latvian invention patent No. 14667. Its application field is fiberconcrete monolithic and modular structural elements production and reconstruction technologies working mainly under bending loading conditions. Fibrous oriented reinforcement creation technique -implies preparation of reinforcing elements where fibre orientation in the necessary direction is obtained prior to concreting using fiber „carpets" prepared by attaching fibers to flexible warp with the necessary fiber concentration. It is worth mentioning that the use of such reinforcement elements leads to the possibility to prepare ,carpets" with nonuniform fiber concentrations and "carpets” with differently oriented fibers. In our case reinforcing 
„carpet” (or „,carpets”) were placed in the mould into the concrete at the necessary depth. With the opening of the cracks in the loaded structural element, fibers which bridge the cracks are stretched and start to pull out of concrete. Optimizing geometrical form of the fibers it is possible to govern crack opening process.

In the Latvian invention patent No. 14684 fiberconcrete reinforcing device is described, which can be used in fiberconcrete monolithic and prefabricated structural elements working under bending, buckling, shear and other loading conditions, as well as in curved element production and reconstruction processes. Application of the device allows to orient and to dose fibers in concrete according to the amount and direction. If a fiberconcrete structural element starts to crack, fibers which bridge the cracks are stretched and start to pull out of concrete. In this case, if fibers of the necessary geometrical form are used, it is possible to govern the entire cracks opening process.

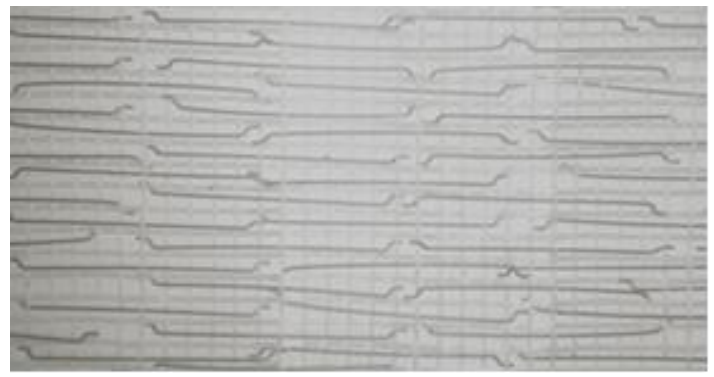

Fig. 1. Reinforcing „carpet” with fibers that was used in our experiments.

All fibers were oriented in the direction of tensile stress (see Fig.1). Three identical prisms of each type of nonhomogeneous fiber reinforced concrete were prepared. Beams were tested under four point bending conditions using Controls Automax 5 testing machine. Increasing external applied load, single macro-crack started to appear at the bottom side of the beam (in every test).

\section{Mechanical properties of fibre concrete}

Verification of mechanical properties was performed by 4-point bending test method. Test samples were tested after 28 days.

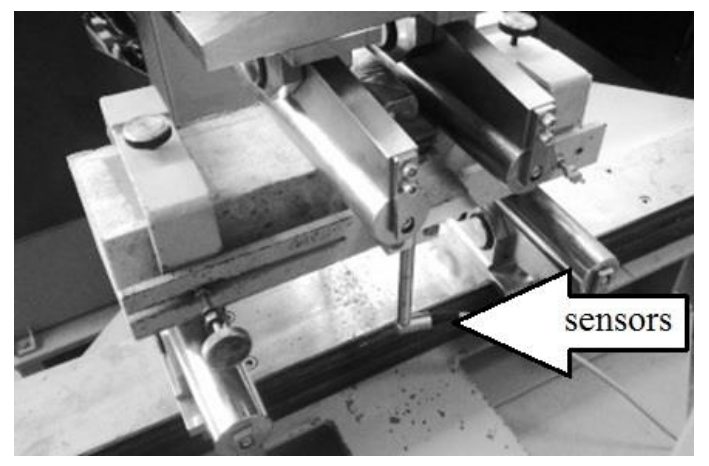

Fig. 2. Testing under four point bending conditions.

Linear displacement measuring sensors were placed on both sides of the testing sample (see Fig. 2). Computer guided growing load was applied. Fine-grained concrete composition was chosen for the samples preparation. Each prism was accompanied by two sensors, which recorded the actual vertical deflection of the beam under increasing load. All results were recorded using external computer and data acquisition module "Spider 8". All data were stored in the computer for further processing and analysis. Simultaneously, concrete cubs with the dimensions $100 \times 100 \times 100 \mathrm{~mm}$ were tested by compression. Strength of fiber reinforced concrete according to the test results corresponded to class C70/85 (European committee for standardization. 2000). Seven groups of differently fabricated fiberconcrete prisms (three samples in each group) were fabricated.

Table 1. Distribution and concentration of fibers in specimens

\begin{tabular}{|c|c|}
\hline $\begin{array}{c}\text { Group } \\
\text { No. }\end{array}$ & Fiber distribution method in the specimens \\
\hline $\begin{array}{l}\text { Group } \\
\text { No. } 1 .\end{array}$ & $\begin{array}{l}30 \mathrm{~mm} \text { long fibers }\left(60 \mathrm{~kg} / \mathrm{m}^{3}\right) \text { mixed in concrete mixer } \\
\text { and homogeneously dispersed in the specimen (classical } \\
\text { method) (see Figure } 3 \text { ) }\end{array}$ \\
\hline $\begin{array}{l}\text { Group } \\
\text { No. } 2 .\end{array}$ & $\begin{array}{l}\text { 1. } 1 / 10 \text { of the total amount }\left(60 \mathrm{~kg} / \mathrm{m}^{3}\right) \text { of } 60 \mathrm{~mm} \text { long } \\
\text { fibers was introduced in each „,carpet”. Fibers were } \\
\text { oriented along the prism longitudinal axis. } 10 \text { carpets } \\
\text { separated by } 10 \mathrm{~mm} \text { thick concrete layers without fibers } \\
\text { (10 layers in total) were stacked in the mould (see } \\
\text { Figure 4). }\end{array}$ \\
\hline $\begin{array}{l}\text { Group } \\
\text { No. } 3 .\end{array}$ & $\begin{array}{l}\text { 1. } 1 / 5 \text { of the total amount of } 60 \mathrm{~mm} \text { long fibers } \\
\left(60 \mathrm{~kg} / \mathrm{m}^{3}\right) \text { was introduced in each ,carpet”. Fibers were } \\
\text { oriented along the prism longitudinal axis. } 5 \text { carpets } \\
\text { separated by } 10 \mathrm{~mm} \text { thick concrete layers without fibers } \\
\text { were stacked in the mould (see Figure } 5) \text { and were } \\
\text { covered by } 60 \mathrm{~mm} \text { of concrete without fibers. }\end{array}$ \\
\hline $\begin{array}{l}\text { Group } \\
\text { No. } 4 .\end{array}$ & $\begin{array}{l}\text { 1. } 25 \mathrm{~mm} \text { of concrete }-1 / 2 \text { of the total amount of } \\
30 \mathrm{~mm} \text { long fibers }\left(60 \mathrm{~kg} / \mathrm{m}^{3}\right) \text { was pressed into concrete; } \\
\text { 2. } 25 \mathrm{~mm} \text { of concrete }-1 / 2 \text { of the total amount of } \\
30 \mathrm{~mm} \text { long fibers }\left(60 \mathrm{~kg} / \mathrm{m}^{3}\right) \text { was pressed into concrete; } \\
\text { 3. } 50 \mathrm{~mm} \text { of concrete without fibers }\end{array}$ \\
\hline $\begin{array}{l}\text { Group } \\
\text { No. } 5 .\end{array}$ & $\begin{array}{l}\text { 1. } 25 \mathrm{~mm} \text { of concrete }-1 / 3 \text { of the total amount of } \\
30 \mathrm{~mm} \text { long fibers }\left(60 \mathrm{~kg} / \mathrm{m}^{3}\right) \text { was pressed into concrete; } \\
\text { 2. } 25 \mathrm{~mm} \text { of concrete }-1 / 3 \text { of the total amount of } \\
30 \mathrm{~mm} \text { long fibers }\left(60 \mathrm{~kg} / \mathrm{m}^{3}\right) \text { was pressed into concrete; } \\
\text { 3. } 25 \mathrm{~mm} \text { of concrete }-1 / 3 \text { of the total amount of } \\
30 \mathrm{~mm} \text { long fibers }\left(60 \mathrm{~kg} / \mathrm{m}^{3}\right) \text { was pressed into concrete; } \\
\text { 4. } 25 \mathrm{~mm} \text { of concrete without fibers }\end{array}$ \\
\hline $\begin{array}{l}\text { Group } \\
\text { No. } 6 .\end{array}$ & $\begin{array}{l}\text { 1. } 55 \mathrm{~mm} \text { of concrete }-30 \mathrm{~mm} \text { long fibers }\left(60 \mathrm{~kg} / \mathrm{m}^{3}\right) \\
\text { were pressed into concrete; } \\
\text { 2. } 45 \mathrm{~mm} \text { of concrete without fibers }\end{array}$ \\
\hline $\begin{array}{l}\text { Group } \\
\text { No. } 7 .\end{array}$ & $\begin{array}{l}\text { 1. } 25 \mathrm{~mm} \text { of concrete }-2 / 3 \text { of the total amount of } \\
30 \mathrm{~mm} \text { long fibers }\left(60 \mathrm{~kg} / \mathrm{m}^{3}\right) \text { were pressed into concrete; } \\
\text { 2. } 75 \mathrm{~mm} \text { of concrete }-1 / 3 \text { of the total amount of } \\
30 \mathrm{~mm} \text { long fibers }\left(60 \mathrm{~kg} / \mathrm{m}^{3}\right) \text { was pressed into concrete }\end{array}$ \\
\hline
\end{tabular}

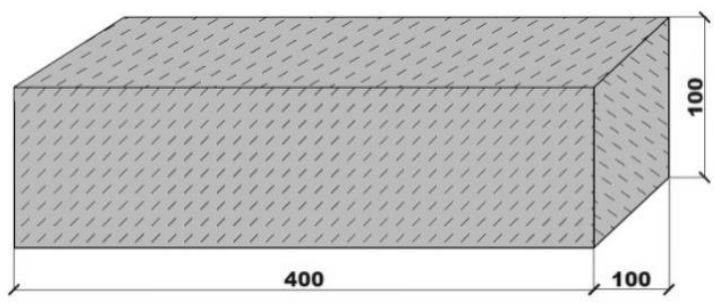

Fig. 3. Group 1 with $30 \mathrm{~mm}$ long fibers homogeneously dispersed in the specimen's volume.

Short description of each group of specimens is presented in Table 1. Group 1 consists of fiber reinforced concrete with $30 \mathrm{~mm}$ long fibers homogeneously dispersed in the sample volume. Fibers were added to the concrete mix during the concrete mixing process and moulds were 
filled by such fiberconcrete for specimens representing Group 1 (see Fig. 3). These prisms were used as a reference.

As it is seen in Table 1, while the total amount of fibers is identical for all seven groups of specimens (in average, fiber concentration in each prism body is $60 \mathrm{~kg} / \mathrm{m}^{3}$ ), the difference lies in their spatial distributions. For specimens of Groups 2, 3, 4, 5, 6 and 7 fibers are distributed in different layers with various fiber concentrations in each layer and various layer positions. These specimens can be defined as layered prisms with oriented distribution of fibers in them. For the specimens from Groups 2, 3, 4, 5, 6 and 7 moulds were gradually filled with the concrete mix according to the description of each group.

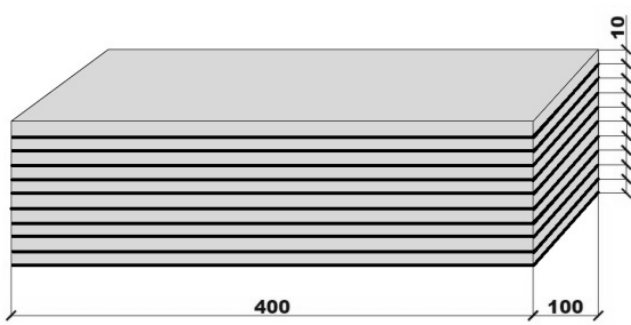

Fig. 4. Group 2, 10 „,carpets” are separated by $10 \mathrm{~mm}$ thick concrete layers without fibers (10 layers in total).

For the specimens from Groups 2 (see Fig. 4) and 3 (see Fig. 5a,b) fibers reinforcing ,carpets” are placed in the mould into concrete at the necessary depth and with fibers oriented in the necessary direction, covering the whole horizontal cross-section of the prism according to the patent No. 14684 and No. 14667 technology.

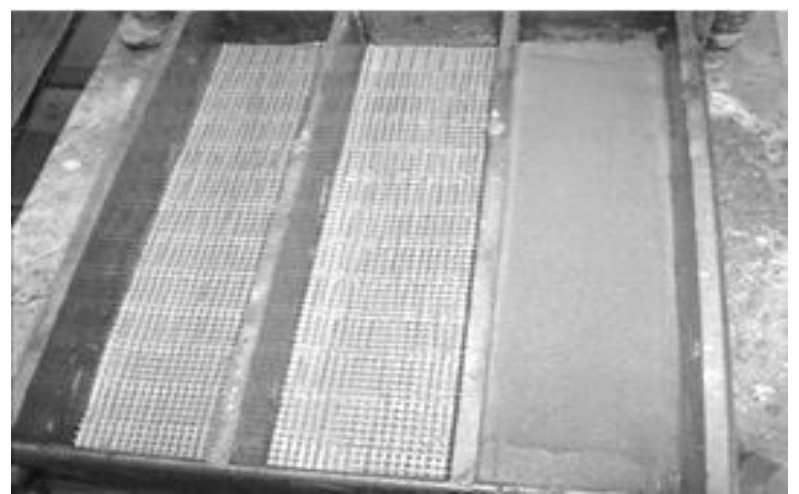

Fig. 5a. „Carpets” with steel fibers are placed into moulds and covered by concrete.

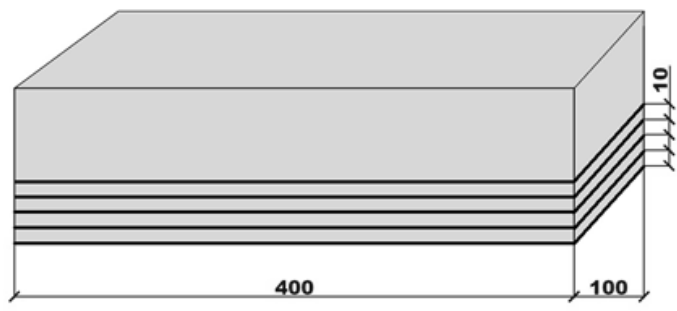

Fig. 5.b. Group 3, 5 ,carpets” separated by $10 \mathrm{~mm}$ thick concrete layers forming the bottom part of each sample, upper part was filled by concrete without fibers.

For the specimens from Groups 4, 5, 6 and 7 fibers were pressed by a steel grid into the concrete in the full length of the prism, according to the patent No. 14257 technology. Formwork is filled of concrete without fibers, fibers were uniformly scattered on the concrete surface in the mould and were pressed into the concrete. For the specimen from Group 4 (see Fig. 6) mould was filled by $25 \mathrm{~mm}$ layer of concrete mix, then fibers $(1 / 2$ of the total amount of fibers $60 \mathrm{~kg} / \mathrm{m}^{3}$ ) were uniformly scattered on the concrete surface in the mould and were pressed into the concrete. Then next $25 \mathrm{~mm}$ layer of concrete was filled and last $1 / 2$ of the total amount of fibers $\left(60 \mathrm{~kg} / \mathrm{m}^{3}\right)$ was uniformly scattered on the concrete surface in the mould and was pressed into the concrete (forming 2 layers with fiberconcrete in the mould), after that last $50 \mathrm{~mm}$ thick layer of concrete without fibers was filled in the mould.

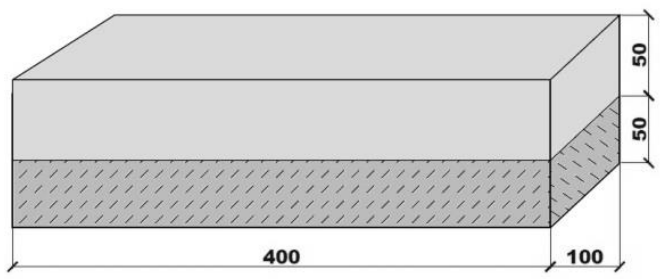

Fig. 6. Group 4. 1/2 of the total amount of fibers was pressed into the bottom concrete ply with thickness $25 \mathrm{~mm}$; next $1 / 2$ of the total amount of fibers was pressed into the next (counting from the bottom) concrete ply with thickness $25 \mathrm{~mm}$. Then the mould was filled by $50 \mathrm{~mm}$ of concrete without fibers.

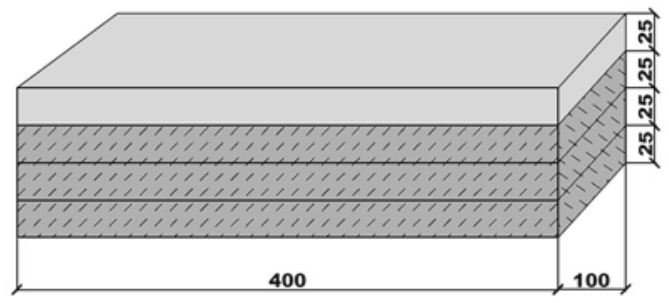

Fig. 7. Group 5 with three bottom layers having even amount of fibers and upper $25 \mathrm{~mm}$ thick layer without fibers.

For the specimen from Group 5 (see Fig. 7) mould was filled by $25 \mathrm{~mm}$ layer of concrete mix, then fibers $(1 / 3$ of the total amount of fibers $60 \mathrm{~kg} / \mathrm{m}^{3}$ ) were uniformly scattered on the concrete surface in the mould and were pressed into concrete. This operation was repeated thrice, after that last $25 \mathrm{~mm}$ thick layer of concrete without fibers was filled in the mould.

For the specimen from Group 6 (see Fig. 8) mould was filled with concrete mix up to $55 \mathrm{~mm}$ and all fibers $\left(60 \mathrm{~kg} / \mathrm{m}^{3}\right)$ were uniformly scattered on the concrete surface in the mould and were pressed into the concrete. Fibers were pressed by a steel grid. Finally, the mould was filled with concrete mix up to $100 \mathrm{~mm}$. For the specimen from Group 7 (see Fig. 9) mould was filled with $25 \mathrm{~mm}$ layer of concrete mix, then fibers $(2 / 3$ of the total amount of fibers $60 \mathrm{~kg} / \mathrm{m}^{3}$ ) were uniformly scattered on the concrete surface in the mould and were pressed into concrete, then $75 \mathrm{~mm}$ thick concrete (without fibers) layer was added and after that fibers (1/3 of the total amount of fibers $60 \mathrm{~kg} / \mathrm{m}^{3}$ ) were uniformly scattered on the concrete prism surface and were pressed into the concrete. 


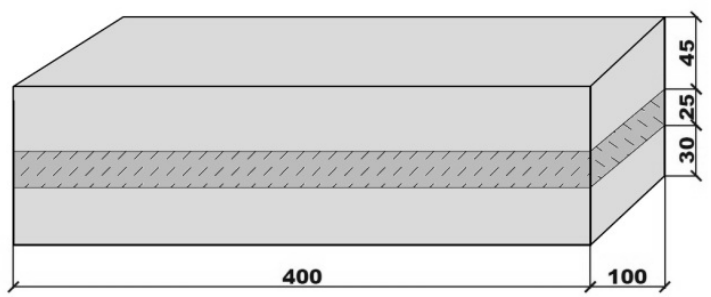

Fig. 8. In Group 6 each sample has concrete in the bottom and upper layers without fibers and one layer in the middle with fibers.

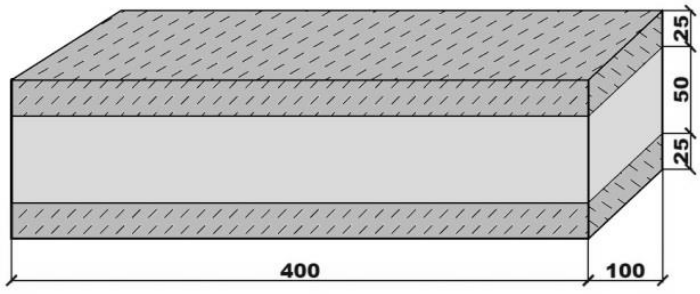

Fig. 9. Group 7, bottom and upper layers have fibers. The layer in the middle is without fibers.

During the testing vertical deflection in the centre of each prism was measured in a real time scale. Sensors were connected through the data acquisition unit to computer, where the obtained data were recorded and were available after the experiments.

\section{Results and discussion}

Specimens were tested under four point bending conditions till the macro crack opening reached $4-10 \mathrm{~mm}$.

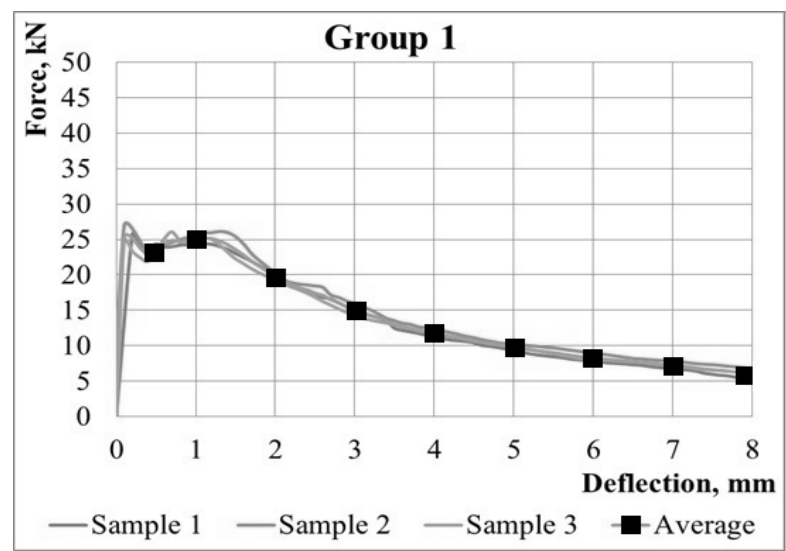

Fig. 10. Load - vertical deflection graphs for specimens in Group No. 1.

Load bearing - vertical deflection in the centre of each prism graphs for the specimens of Group 1 are shown in Fig. 10.The diagram shows the experimental curve of each specimen as well as the average value curve. Three stages are seen in each curve, first of them is linear elastic deflection (corresponds to deflection under $0.01 \mathrm{~mm}$ ).

At this stage fiber reinforced concrete prisms become deformed without visible crack openings.

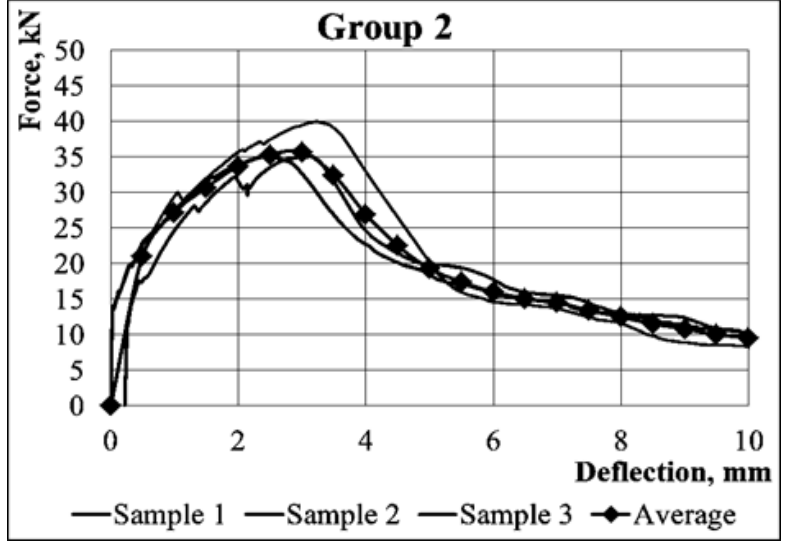

Fig. 11. Load - vertical deflection graphs for specimens in Group No. 2.

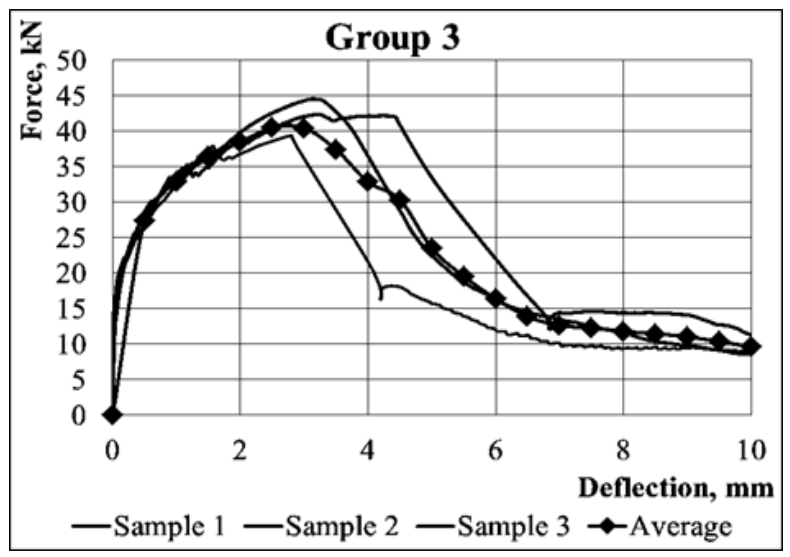

Fig. 12. Load - vertical deflection graphs for specimens in Group No. 3.

Fibers in the concrete do not bear significant load. The next stage begins with deviation of the curves from the straight line and terminates reaching the maximum value on the curve (with deflection of prisms $0.75 \mathrm{~mm}-1 \mathrm{~mm}$ ). At this stage concrete micro cracks accumulate and grow forming macro crack network. The macro cracks are formed perpendicularly to the longitudinal axis of the prism. Density of macro crack network depends on specimen geometry, size of fibers and their amount. Fibers traversing macro cracks begin to bear load, while cracks are still invisible on the outer surface of the specimen. The crack with the lowest load carrying capacity (one with the lower amount of fibers traversing it or fibers located and oriented in a less optimal way) starts to open. It proceeds in the following way: fibers bearing load detach from the concrete and start pulling out from one or both ends. Individual load carrying capacity of the fiber depends on its distribution relative to the crack plane and how far it is extracted. 


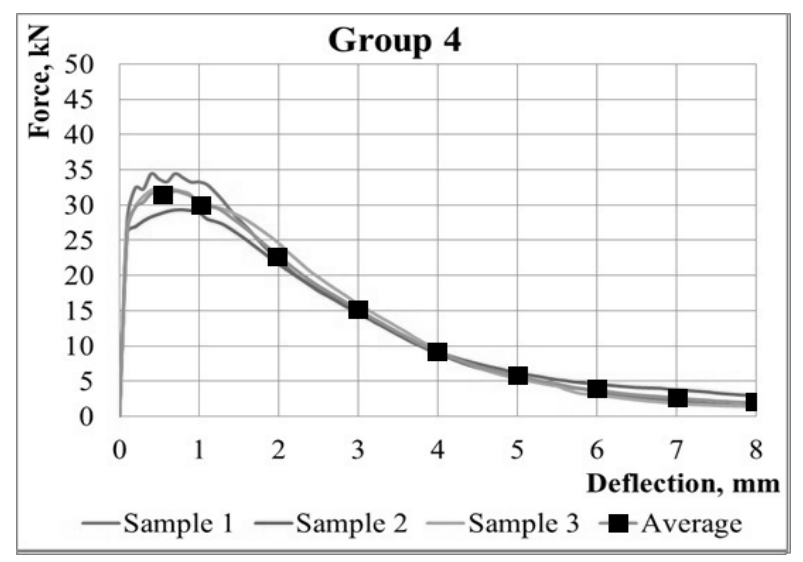

Fig. 13. Load - vertical deflection graphs for specimens in Group No. 4.

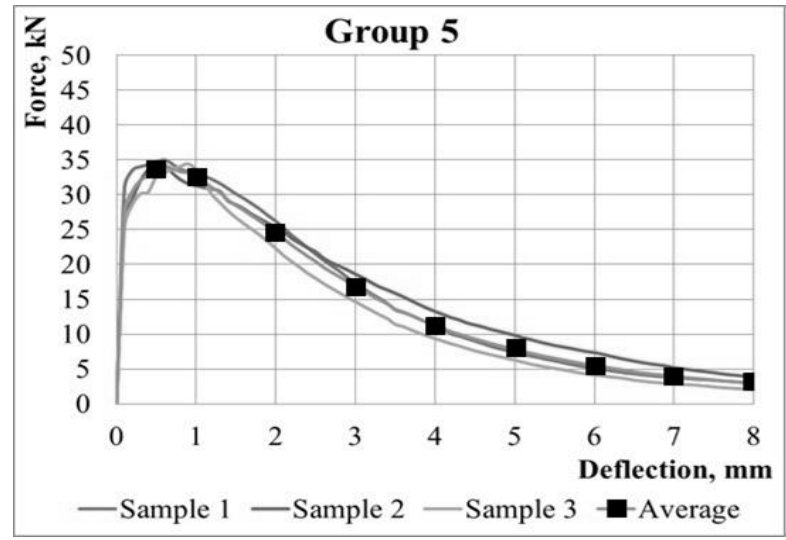

Fig. 14. Load - vertical deflection graphs for specimens in Group No. 5.

Experimental observation of fiber pull-out micromechanics (Krasnikovs et al. 2012) showed that the maximum load carrying capacity of a single fiber depends on the distribution of fiber in the direction of extraction force and how much the fiber has been extracted. The third stage is characterised by the decline of total load carrying capacity of the fiber. The capacity decreases proportionally to the size of crack opening. Load bearing - vertical deflection in the centre of prism for the specimens of Groups 2, 3, 4, 5, 6 and 7 are given in Figures 10-16.

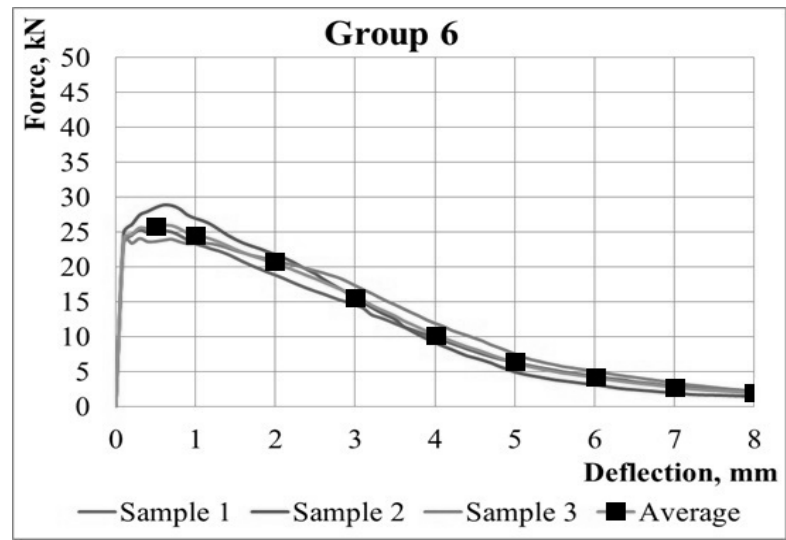

Fig. 15. Load - vertical deflection graphs for specimens in Group No. 6.

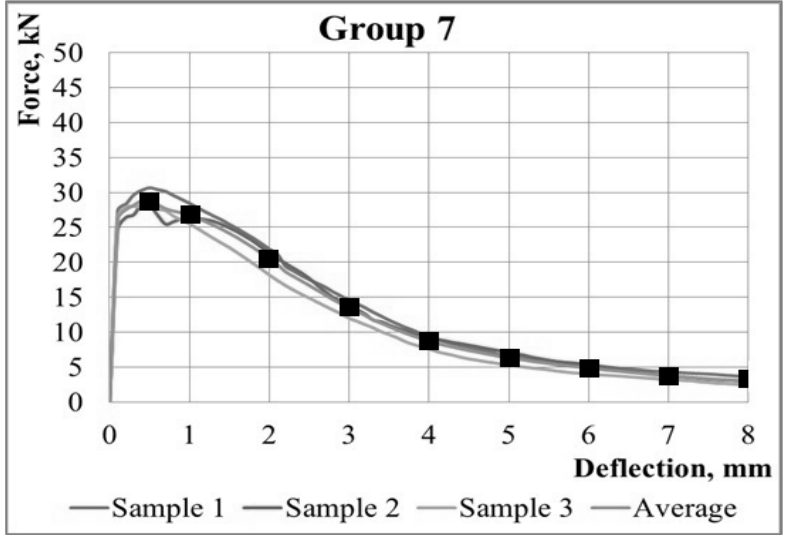

Fig. 16. Load - vertical deflection graphs for specimens in Group No. 7.

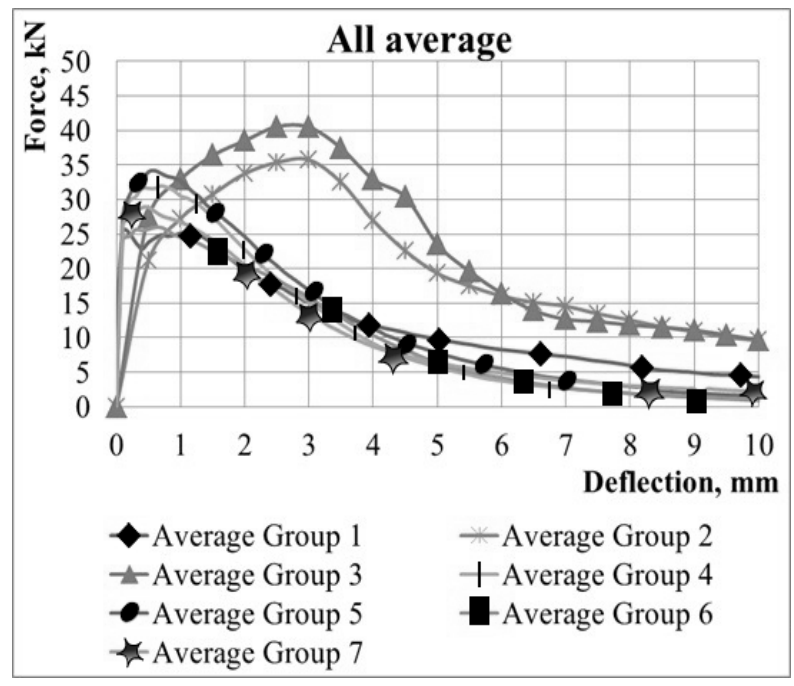

Fig. 17. Load vertical deflection graphs for specimens in comparison to average of all sample groups.

Diagrams in Figure 17 show the average experimental curves from three specimens. As it can be observed, Group 3 reaches the highest load carrying capacity during crack opening stage due to the highest concentration of $60 \mathrm{~mm}$ long fibers compared to other groups in the lower part of the prism, which bears the maximum tensile load.

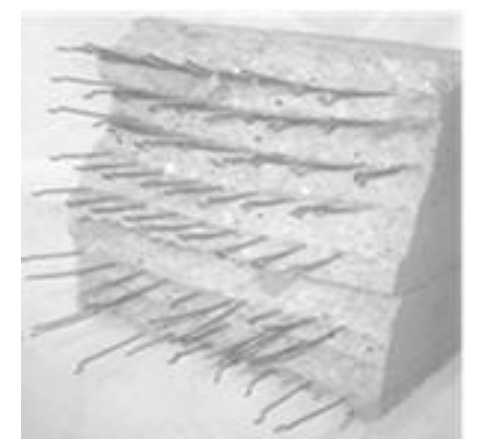

Fig. 18. Failure surface for the sample with steel fibers stacked in 10 layers.

As it can be observed, Group 1 (reference) specimens reach lower average load carrying capacity in the third stage (macro cracks) compared to the specimens with non-homogeneous distribution of fibers. Certain similar 
tendencies can be observed among the diagrams of average results of specimens - the maximal load carrying capacity is reached with deflection of prisms $0.75 \mathrm{~mm}-$ $1 \mathrm{~mm}$, which correlates with the crack opening size. Another important question is dependence of fiberconcrete structural element post cracking behaviour on fiber orientation in the material. In Groups 2 and 3, $60 \mathrm{~mm}$ long steel fibers were entangled into slim glass fiber net (see Fig. 1, 5a). Nets with fibers oriented in one direction (,carpets") were placed into moulds, covered by concrete and were vibrated. Samples with steel fibers stacked in 10 layers and samples with 10 layers of glass fiber nets without steel fibers were tested for 4 point bending. Sample failure surface is shown in Fig. 18. In Figure 19 it is possible to see force-deflection diagrams for samples having 10 glass fiber nets without steel fibers, placed at equal distance one from another in the prism. It is possible to compare this diagrams with the diagrams in Figure 11, where diagrams for samples with steel fibers are shown. According to the tests results, samples with non-homogeneous fiber distribution in the sample volume demonstrated higher load carrying capacity. Explanation for this phenomenon may be as follows - they had higher fiber concentration working under pull-out conditions, which was subjected to tensile loads (see Fig. 20).

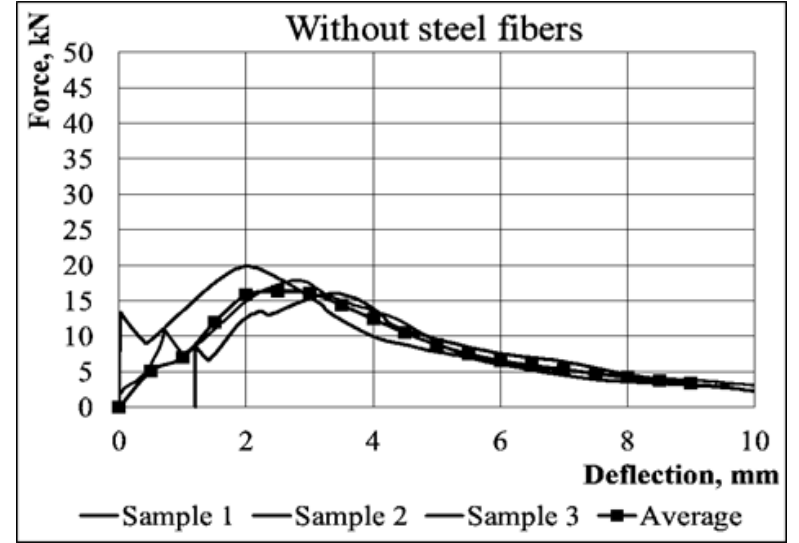

Fig. 19. Force - deflection curves for samples having 10 glass fiber nets (placed at equal distance one from other) without steel fibers.
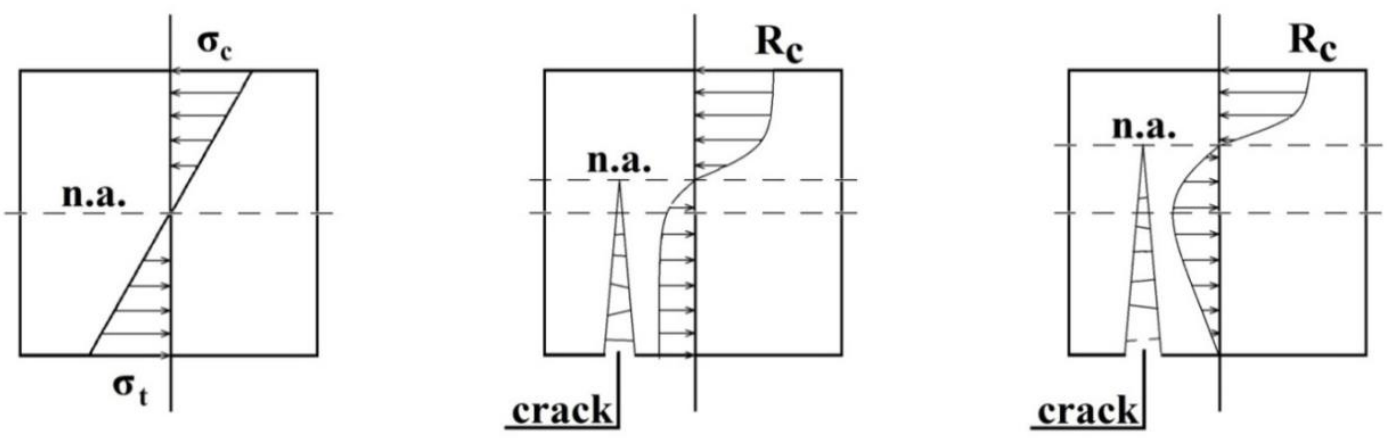

Fig. 20. Distribution of stresses in the bended beam with macro crack bridged by fibers.

\section{Conclusion}

Different types of fiberconcrete having nonhomogeneous fiber distribution in the concrete volume were elaborated and investigated under 4 point bending conditions. According to the performed bending tests, specimens with chaotic fiber distribution in samples volume show lower average load carrying capacity during crack forming and opening stages compared with the specimens, which had non-homogeneous distribution of fibers.

\section{Acknowledgments}

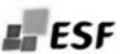

This work has been supported by the European Social Fund within the project «Support for the implementation of doctoral studies at RTU».

\section{References}

Bekaert., 2013. EC Declaration of Performance Dramix ${ }^{\circledR}$.

European committee for standardization., 2000. European standard EN 206-1 2000. Concrete - Part 1 Specification, performance, production and conformity., pp. 1-72.

Krasnikovs, A. et al., 2012. Post-Cracking Behaviour of High Strength (Nano Level Designed) Fiber Concrete Prediction and Validation. In CD-Proceedings of 4th International Symposium on Nanotechnology in Construction. Crete, Greece, pp. 6.

Lapsa, V.-Ā.; Krasnikovs, A.; Strauts, K., 2011. Process and device for manufacturing fiberconcrete non-homogeneous structural elements.

Lusis, V.; Krasnikovs, A., 2013a. Bending strength of layered fiberconcrete prisms. In 4th International Conference CIVIL ENGINEERING`13 Proceedings Part I. Jelgava, pp. 117-121.

Lusis, V.; Krasnikovs, A., 2013b. Method for reinforcing the fiber concrete structure. pp. 1-8.

Lusis, V.; Krasnikovs, A., 2013c. Technical device for fiberconcrete oriented reinforcement. pp. 1-9.

Nicolay, J., 1984. Stehlfaserspritzbeton Stoffgesetze, Grundsätzliche Eignung, Gütenachweis. Berichte des Instituts für Konstruktiven Ingenieurbau. Heft 42,

Roik, K.; Dieckmann, C.; Schwalbenhofer, K., 1987. Verbundstützen mit Stahlfaserbeton. Der Bauingenieur, 62, pp. 172-182.

Schorn, X., 1985. Stahlfaserbeton in der Materialprüfung. Betonwerk und Fertigteiltechnik. pp. 741-746. 